\title{
EFEKTIVITAS BAKTERI ANTAGONIS (Pseudomonas sp.) UNTUK MENGENDALIKAN PENYAKIT CABANG JAMUR UPAS (Corticium salmonicolor)
}

\author{
The Effectiveness of Antagonistic Bacteria (Pseudomonas sp.) as \\ Biological Control of Pink Disease (Corticium salmonicolor) \\ Zaida FAIRUZAH, Cici Indriani DALIMUNTHE, dan AIDI-DASLIN \\ Balai Penelitian Sungei Putih, Pusat Penelitian Karet \\ Galang, Deli Serdang, Sumatera Utara, PO BOX 1415 Medan 20001 \\ Email : zaida_fairuzah@yahoo.com
}

Diterima : 30 Juli 2013 / Direvisi : 2 September 2013 / Disetujui : 27 Maret 2014

\begin{abstract}
The pink disease on stems and branches of rubber are not as popular as on the leaves or root though the losses caused were higher mainly in the area with high humidity and rainfall. It is important to search for antagonistic microorganism that effectively and efficiently controls pink disease such as Pseudomonas sp bacteria. This research was conducted to affirm the effectiveness of it at field. The research was done by lubricating Pseudomonas $s p$. to the infected branch with varying degrees of attack. The treatment was applied four times with intervals of one week. The research design used was non factorial randomized block design with 7 treatments consisting of Pseudomonas sp. (without storage, one month storage, two months storage, and three months storage), two kinds of chemical fungicide (Triadimefon and Heksakonazol), and control (without application). Each treatments was repeated three times with 20 plants sampled at each unit. The observations were carried out every months after the fourth applications with observed parameter of recovery percentage. Data were analyzed using analysis of variance and continued with Duncan Test. Three months storage showed the best ability with recovery percentage 80,49\%. This was not significantly different from chemically treated even significantly different with controls.
\end{abstract}

Keywords: Hevea brasiliensis, Pink disease (Corticium salmonicolor), biological control, antagonistic bacteria (Pseudomonas sp.)

Abstrak
Penyakit jamur upas (Corticium
nicolor) pada batang dan cabang tanaman
tidak sepopuler serangan penyakit daun
un akar meskipun demikian dampak

\section{Abstrak}

salmonicolor) pada batang dan cabang tanaman karet tidak sepopuler serangan penyakit daun maupun akar meskipun demikian dampak kerugian yang disebabkan oleh kerusakan cabang dan batang cukup tinggi terutama di daerah yang mempunyai curah hujan tinggi dan kelembaban tinggi. Untuk itu perlu ditemukan mikroorganisme antagonis efektif dan efisien untuk pengendalian penyakit cabang jamur upas seperti bakteri Pseudomonas sp. Oleh karena itu, perlu penegasan mengenai keefektifan dari Pseudomonas sp. tersebut dengan melakukan pengujian kembali. Pengujian dilakukan dengan cara mengoleskan Pseudomonas sp. pada cabang yang terserang jamur upas dengan berbagai tingkat serangan. Perlakuan dilakukan sebanyak empat kali dengan interval satu minggu. Rancangan penelitian yang digunakan adalah Rancangan Acak Kelompok (RAK) non faktorial dengan 7 perlakuan yang terdiri dari Pseudomonas sp (tanpa penyimpanan, satu bulan penyimpanan, dua bulan penyimpanan, dan tiga bulan penyimpanan), dua macam fungisida kimia (Triadimefon dan Heksakonazol), dan kontrol (tanpa aplikasi). Masing-masing perlakuan diulang sebanyak 3 kali dengan 20 tanaman sampel pada setiap unitnya. Pengamatan dilaksanakan setiap bulan setelah aplikasi ke empat dengan parameter persentase kesembuhan penyakit. Data dianalisis menggunakan ANOVA dan dilanjutkan dengan Uji Jarak Berganda Duncan. Hasil penelitian menunjukkan bahwa Pseudomonas sp. dengan penyimpanan selama tiga bulan memiliki kemampuan terbaik mengendalikan penyakit jamur upas di lapangan dengan persentase kesembuhan mencapai 80,49\%. Hal ini tidak berbeda nyata dengan perlakuan fungisida kimia tetapi berbeda nyata bila dibandingkan dengan kontrol.

Kata kunci: Karet alam, penyakit jamur upas (Corticium salmonicolor), pengendalian biologi, bakteri antagonis (Pseudomonas sp.) 


\section{PENDAHULUAN}

Gangguan penyakit merupakan kendala serius yang sering dihadapi di lapangan terutama dalam usaha peningkatan produksi. Pada cabang tanaman karet, penyakit penting yang menimbulkan kerusakan parah adalah penyakit jamur upas atau pink disease. Penyakit ini disebabkan oleh Corticium salmonicolor Berk. \& Br. yang tergolong dalam kelas Basidiomycetes. Penyakit ini menyerang tanaman yang masih muda, yakni tanaman yang berumur antara $3-7$ tahun, serta diduga pada klon-klon baru yang bertajuk lebat (Pawirosoemardjo et al., 1992). Ciri khas penyakit jamur upas adalah kematian cabang, kanker batang, adanya pertumbuhan miselia berwarna pink pada permukaan yang terinfeksi, dan terkadang menyebabkan kematian tanaman (Gezahgne et al., 2003). Pengujian untuk mencari cara pengendalian penyakit jamur upas pernah dilakukan sebelumnya walaupun pengujian ini belum tuntas. Metode pengendalian yang sering diuji adalah dengan menggunakan fungisida kimia. Penggunaan mikroorganisme untuk mengendalikan penyakit jamur upas masih sangat terbatas.

Sampai saat ini pengembangan metode pengendalian biologis telah melakukan eksplorasi mikrobia antagonis sebagai sebuah alternatif lain dari penggunaan senyawa kimia telah menarik perhatian yang intensif (Lutchmeah dan Cooke, 1985). Langkah awal untuk mengembangkan sistem pengendalian biologis adalah mengisolasi dan mengidentifikasi organisme antagonis yang memiliki potensi untuk menekan penyakit. Karena organisme antagonis diduga memiliki kemampuan untuk bersaing lebih baik di lingkungan dimana mereka berevolusi dan beradaptasi, eksplorasi agensia hayati haruslah berasal dari sistem yang sama dimana mereka akan diaplikasikan (Nelson dan Powelson, 1988).

Sejumlah mikroba atau mikroorganisme telah dilaporkan dalam berbagai penelitian ternyata efektif sebagai agen pengendalian hayati hama dan penyakit tumbuhan, diantaranya adalah dari genus-genus Bacillus, Gliocladium, Penicillium, Pseudomonas, Trichoderma, dan Verticillium (Hasanuddin, 2003). Mikroorganisme-mikroorganisme itu dapat bertempat tinggal dalam sel (Jacobs et al., 1985), dalam celah ruang antar sel (Patriquin dan Oring-Bereiner, 1978) atau dalam sistem vaskular (Bell et al., 1995). Karena itu mikroorganisme berupa jamur atau bakteri itu sering disebut sebagai endofitik. Hallman et al (1997 mendefenisikan bakteri endofitik merupakan bakteri yang dapat diisolasi dari permukan jaringan tanaman yang tidak terinfeksi atau yang dapat diekstraksi dari ruang antar sel tetapi tidak berbahaya bagi tanaman. Strain bakteri ini mengeluarkan sistem pelindung yang melawan patogen ketika diinokulasikan ke benih atau ke dalam jaringan tanaman (Jetiyanon dan Klopper, 2002). Terkadang di dalam jaringan tanaman, bakteri endofitik terletak pada jaringan tanaman yang spesifik atau terkoloni secara sistematik, membawa unsur-unsur yang dibutuhkan (Hallman et al., 1997). Genus Actinobacter, Agrobacterium, Alcaligenes, Bacillus, Clavibacter, Enterobacter, Erwina, Klebsiella, Phyllobacterium, Pseudomonas dan Serratia dilaporkan sebagai bentuk endofitik beberapa tanaman (Mclnroy dan Kloepper, 1991; Sturz et al., 1997). Pada pengujian tahun 2009 dalam skala laboratorium, Pseudomonas sp. menunjukkan kemampuan penghambatan jamur upas pada medium kayu mencapai $72 \%$. Bakteri ini juga mampu menyembuhkan penyakit jamur upas hingga 66,65\% pada salah satu perkebunan karet di daerah Deli Serdang (Fairuzah dan Daslin, 2011).

Pengendalian dengan memanfaatkan mikroorganisme antagonis terhadap jamur upas belum pernah diterapkan di Indonesia. Untuk itu perlu dilakukan pengujian kembali dengan memanfaatkan mikroorganisme antagonis tersebut sehingga diharapkan lebih dipastikan memberikan hasil penekanan intensitas serangan penyakit jamur upas yang lebih maksimal dan ramah lingkungan.

\section{BAHAN DAN METODE}

Penelitian ini dilaksanakan di Kebun Batang Serangan, PTP Nusantara II tahun 2011 (Gambar 1) pada tanaman karet berumur tiga tahun (TBM 3). Lokasi tersebut terpilih karena termasuk daerah beriklim basah dan banyak terdapat serangan penyakit jamur upas. Pemeliharaan 


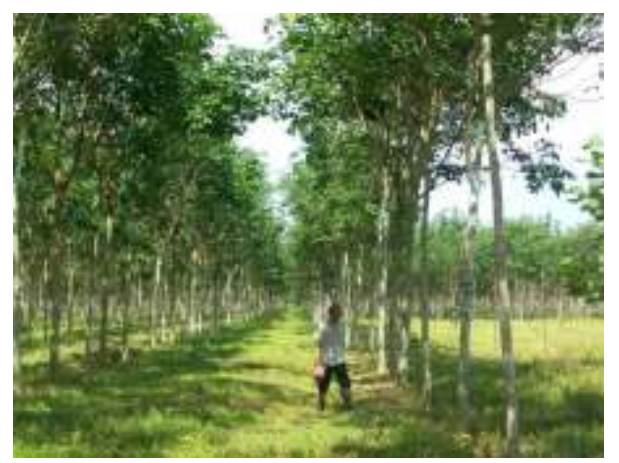

Gambar 1. Lokasi pengujian biofungisida di Kebun Batang Serangan Figure 1. Biofungicide testing location in Batang Serangan Plantation

tanaman di lapangan tetap dilakukan berdasarkan teknik budidaya yang berlaku di lokasi setempat, antara lain dalam hal penyiangan dan pemupukan, sesuai norma kultur teknis yang berlaku di PTP Nusantara II.

Bahan-bahan yang digunakan dalam penelitian ini adalah pepton, beef extract, $\mathrm{NaCl}$, agar, aquades steril, bahan isolat bakteri antagonis Pseudomonas sp., fungisida berbahan aktif Triadimefon dan Hexaconazol. Alat-alat yang digunakan antara lain petri dish, erlenmeyer, mikroskop, jarum inokulasi, bor gabus, tabung reaksi, beaker glass, laminar air flow cabinet, otoklaf, neraca analitik, pinset, kuas, wadah, cat, label nama. Rancangan percobaan yang digunakan adalah Rancangan Acak Kelompok (RAK) non faktorial dengan 7 perlakuan dan 3 ulangan.
Setiap perlakuan terdiri dari 20 tanaman sampel dalam setiap ulangan. Setiap perlakuan pada penelitian dapat dilihat pada Tabel 1.

Biofungisida yang digunakan setelah penyimpanan selama 1,2 , atau 3 bulan sebelumnya disimpan di laboratorium dengan suhu ruang $\pm 25^{\circ} \mathrm{C}$. Biofungisida berbahan aktif bakteri antagonis Pseudomonas sp. tersebut disimpan dalam bentuk larutan. Sebelum tanaman diaplikasikan, dilakukan pengamatan awal intensitas serangan penyakit jamur upas. Setelah itu intensitas serangan penyakit juga diamati pada satu bulan setelah aplikasi (1 BSA, 2 BSA, dan 3 BSA). Perhitungan intensitas serangan berdasarkan skala serangan jamur upas pada setiap tanaman (Tabel 2).

Tabel 1. Perlakuan biofungisida dan fungisida yang diuji Table 1. Treatments of biofungicides and fungicides which were tested

\begin{tabular}{cl}
\hline No. & $\begin{array}{c}\text { Perlakuan } \\
\text { Treatments }\end{array}$ \\
\hline 1. & Biofungisida tanpa penyimpanan \\
2. & Biofungisida setelah disimpan 1 bulan \\
3. & Biofungisida setelah disimpan 2 bulan \\
4. & Biofungisida setelah disimpan 3 bulan \\
5. & Fungisida Triadimefon \\
6. & Fungisida Heksakonazol \\
7. & Kontrol (tanpa perlakuan) \\
\hline
\end{tabular}


Tabel 2. Skala untuk menentukan intensitas serangan jamur upas Table 2. Scale to determine the attack intensity of pink disease

\begin{tabular}{cl}
$\begin{array}{c}\text { Skala } \\
\text { Scale }\end{array}$ & \multicolumn{1}{c}{$\begin{array}{l}\text { Keterangan } \\
\text { Explanation }\end{array}$} \\
\hline 0 & $\begin{array}{l}\text { Tidak ada serangan. } \\
\text { Terdapat sebaran seperti sarang laba-laba, melekat di permukaan } \\
\text { kulit. }\end{array}$ \\
2 & $\begin{array}{l}\text { Lateks menetes di antara bentukan sarang laba-laba. } \\
\text { Pada jaringan terserang terdapat selaput (miselia putih) tebal } \\
\text { berwarna kemerahan, ada lateks yang menetes berwarna coklat, daun } \\
\text { pada ranting menguning. } \\
\text { Jaringan kulit membusuk, berwarna kehitaman, bila kulit dikelupas } \\
\text { akan terlihat jaringan kayu, ada keterlibatan serangga, daun pada } \\
\text { ranting gugur, jaringan terinfeksi patah. } \\
\text { Cabang atau batang yang terserang mati, patah pada bagian cabang } \\
\text { yang utama. }\end{array}$ \\
\hline Sumber (Source) : Budiman dan Amypalupy (2003)
\end{tabular}

Dari hasil skala ditentukan intensitas serangan penyakit jamur upas dengan rumus:

$$
\mathrm{IS}=\frac{\left(\sum(\mathrm{ni} \times \mathrm{vj}) \times 100 \%\right.}{(\mathrm{N} \mathrm{x} \mathrm{V)}}
$$

Keterangan :

IS = Intensitas serangan

$\mathrm{n}=$ skala serangan yang diamati (i) pada tanaman (j)

$\mathrm{N}=$ jumlah tanaman yang diamati

$\mathrm{V}=$ skala serangan tertinggi

Berdasarkan hasil perhitungan intensitas serangan di atas maka dapat dihitung persentase kesembuhan penyakit dengan menggunakan rumus :

Persentase kesembuhan $=\frac{\left(\mathrm{IS}_{\mathrm{A}}-\mathrm{IS}_{\mathrm{P}}\right)}{\mathrm{IS}_{\mathrm{A}}} \times 100 \%$

Keterangan :

$\mathrm{IS}_{\mathrm{A}}=$ intensitas serangan penyakit sebelum aplikasi

$\mathrm{IS}_{\mathrm{P}}=$ intensitas serangan penyakit setelah aplikasi

Data persentase kesembuhan penyakit pada pengamatan tiga bulan setelah diaplikasi biofungisida dan fungisida dianalisis ANOVA kemudian dilanjutkan dengan Uji Jarak Berganda Duncan pada tahap kepercayaan $5 \%$.
Pelaksanaan penelitian pada setiap perlakuan adalah sebagai berikut:

- Perlakuan biofungisida

Perlakuan biofungisida dilakukan dengan cara pelumasan pada bagian tanaman yang terserang jamur upas setiap 7 hari selama sebulan. Dosis yang digunakan tergantung pada besarnya luas serangan penyakit. Pengamatan intensitas serangan jamur upas dilakukan setiap bulan.

- Perlakuan kimiawi

Perlakuan kimiawi dilakukan pengolesan fungisida. Perlakuan pengolesan dilakukan dengan interval satu minggu selama sebulan. Demikian halnya dengan perlakuan biofungisida, dosis yang digunakan tergantung pada besarnya luasan serangan penyakit. Pengamatan intensitas serangan penyakit dilakukan setiap bulan.

\section{HASIL DAN PEMBAHASAN}

Hasil perhitungan intensitas serangan awal (pre aplikasi) berdasarkan pengamatan skala serangan dari setiap tanaman menunjukkan hasil yang bervariasi dengan rataan persentase serangan sekitar 24,33-27,33\% (Tabel 3). Hal ini menunjukkan bahwa penyebaran 
Tabel 3. Intensitas serangan awal jamur upas sebelum aplikasi biofungisida dan fungisida Table 3. Initial intensity of pink disease attack before the application biofungicide and fungicide

\begin{tabular}{lcccc}
\hline \multirow{2}{*}{$\begin{array}{c}\text { Perlakuan } \\
\text { Treatments }\end{array}$} & \multicolumn{2}{c}{$\begin{array}{c}\text { Intensitas serangan ulangan } \\
\text { Attack }\end{array}$} & $\begin{array}{c}\text { Ratensity Replication } \\
\text { (\%) }\end{array}$ & \multirow{2}{*}{$\begin{array}{c}\text { Average } \\
\text { (\%) }\end{array}$} \\
\cline { 2 - 4 } & I & II & III & \\
\hline Biofungisida tanpa penyimpanan & 23,00 & 28,00 & 24,00 & $25,00 \mathrm{a}$ \\
Biofungisida penyimpanan 1 bulan & 24,00 & 33,00 & 22,00 & $26,33 \mathrm{a}$ \\
Biofungisida penyimpanan 2 bulan & 24,00 & 28,00 & 21,00 & $24,33 \mathrm{a}$ \\
Biofungisida penyimpanan 3 bulan & 29,00 & 31,00 & 22,00 & $27,33 \mathrm{a}$ \\
Fungisida Triadimefon & 31,00 & 30,00 & 21,00 & $27,33 \mathrm{a}$ \\
Fungisida Heksakonazol & 24,00 & 30,00 & 22,00 & $25,33 \mathrm{a}$ \\
Kontrol (tanpa perlakuan) & 30,00 & 29,00 & 23,00 & $27,33 \mathrm{a}$ \\
\hline
\end{tabular}

Angka-angka yang diikuti oleh huruf yang berbeda pada kolom yang sama berbeda nyata pada Uji Jarak Berganda Duncan $\mathrm{P}=0,05$

Figures followed by different letter in the same column are significantly different at Duncan Multiple Range Test $P=0,05$

penyakit jamur upas di areal yang dimaksud tergolong merata dan data awal pengamatan menunjukkan perbedaan yang tidak nyata antar perlakuan. Setelah aplikasi menunjukkan penurunan tingkat serangan penyakit setiap bulannya (Tabel 4). Pengendalian biologi terhadap jamur upas yang menyerang tanaman karet di Kebun Batang Serangan memberikan hasil yang positif terhadap tanaman dan tergolong ramah lingkungan. Bakteri antagonis (Pseudomonas sp.) sebagai bahan aktif dari biofungisida yang diuji memberikan pengaruh yang nyata terhadap intensitas serangan penyakit jamur upas bila dibandingkan dengan perlakuan kontrol.

Biofungisida yang bersifat ramah lingkungan ini diharapkan dapat menggantikan fungisida kimia, Lutchmeah dan Cooke (1985) menyatakan bahwa sampai saat ini pengembangan metode pengendalian biologis dengan mengeksploitasi mikrobia antagonis sebagai sebuah alternatif lain dari penggunaan senyawa kimia telah menarik perhatian. Biofungisida yang berbahan aktif mikroba antagonis ini juga diharapkan dapat terus berkembang di alam setelah diaplikasikan sehingga tidak perlu pengulangan aplikasi dengan rentang waktu yang pendek. Nelson dan Powelson (1988) mengemukakan bahwa organisme antagonis diduga memiliki kemampuan untuk bersaing lebih baik pada lingkungan dimana mereka berevolusi dan beradaptasi. Eksplorasi agensia hayati haruslah berasal dari sistem yang sama dimana mereka akan diaplikasikan.

Dari hasil pengamatan yang telah dilakukan apabila dilihat dari faktor lama penyimpanan biofungisida menunjukkan bahwa masa penyimpanan biofungisida selama 3 bulan masih tergolong efektif dalam mengendalikan penyakit jamur upas dan hal ini tidak berbeda nyata dengan perlakuan lainnya kecuali terhadap kontrol. Pengamatan satu bulan setelah aplikasi (1 BSA) menunjukkan bahwa biofungisida berbahan aktif Pseudomonas $s p$. dapat mengendalikan jamur upas secara cepat dan dibandingkan dengan perlakuan fungisida tidak menunjukkan perbedaan yang nyata. Banyak faktor yang mempengaruhi kemampuan suatu mikroba antagonis dalam mengendalikan penyakit diantaranya lingkungan dan populasi bakteri antagonis itu sendiri.

Efektivitas suatu biofungisida dalam mengendalikan penyakit dapat dilihat dari persentase kesembuhan yang diperolehnya dan hal ini dihitung berdasarkan nilai intensitas serangan. Persentase kesembuhan dari setiap perlakuan dapat dilihat pada Tabel 5. Hasil pengamatan 
Tabel 4. Intensitas serangan jamur upas setelah aplikasi Table 4. Attack intensity of pink disease after application

\begin{tabular}{|c|c|c|c|}
\hline \multirow[t]{2}{*}{$\begin{array}{l}\text { Perlakuan } \\
\text { Treatments }\end{array}$} & \multicolumn{3}{|c|}{$\begin{array}{c}\text { Rataan intensitas serangan pada bulan ke- } \\
\text { The average intensity of the attacks in months } \\
(\%)\end{array}$} \\
\hline & I & II & III \\
\hline Biofungisida tanpa penyimpanan & $11,67 a$ & $7,67 a$ & $8,67 a$ \\
\hline Biofungisida penyimpanan 1 bulan & $12,33 a$ & $7,33 a$ & $8,33 a$ \\
\hline Biofungisida penyimpanan 2 bulan & $12,33 a$ & $9,67 a$ & $8,67 a$ \\
\hline Biofungisida penyimpanan 3 bulan & $11,33 a$ & $8,33 a$ & $5,33 a$ \\
\hline Fungisida Triadimefon & $12,67 a$ & $11,00 \mathrm{a}$ & $10,00 \mathrm{a}$ \\
\hline Fungisida Heksakonazol & $10,33 a$ & $9,33 a$ & $11,00 \mathrm{a}$ \\
\hline Kontrol (tanpa perlakuan) & $29,67 \mathrm{~b}$ & $30,00 \mathrm{~b}$ & $28,00 \mathrm{~b}$ \\
\hline
\end{tabular}

Angka-angka yang diikuti oleh huruf yang berbeda pada kolom yang sama berbeda nyata pada Uji Jarak Berganda Duncan $\mathrm{P}=0,05$

Figures followed by different letter in the same column are significantly different at Duncan Multiple Range Test $P=0,05$

Tabel 5. Persentase kesembuhan pada bulan ketiga setelah aplikasi

Table 5. Percentage of recovery in the third month after application

\begin{tabular}{lrrrrr}
\hline \multicolumn{1}{c}{$\begin{array}{c}\text { Perlakuan } \\
\text { Treatments }\end{array}$} & \multicolumn{3}{c}{$\begin{array}{c}\text { Persentase } \\
\text { kesembuhan/ulangan } \\
\text { Percentage of } \\
\text { recovery/ replication }\end{array}$} & \multirow{2}{*}{$\begin{array}{c}\text { Rataan } \\
\text { Average } \\
\text { (\%) }\end{array}$} \\
\cline { 2 - 4 } & I & II & III & \\
\hline Biofungisida tanpa penyimpanan & 52,17 & 71,43 & 70,83 & $65,33 \mathrm{a}$ \\
Biofungisida penyimpanan 1 bulan & 66,67 & 81,82 & 50,00 & $68,35 \mathrm{a}$ \\
Biofungisida penyimpanan 2 bulan & 66,67 & 71,43 & 52,38 & $64,38 \mathrm{a}$ \\
Biofungisida penyimpanan 3 bulan & 79,31 & 83,87 & 77,27 & $80,49 \mathrm{a}$ \\
Fungisida Triadimefon & 80,65 & 60,00 & 42,86 & $63,41 \mathrm{a}$ \\
Fungisida Heksakonazol & 50,00 & 76,67 & 36,36 & $56,58 \mathrm{a}$ \\
Kontrol (tanpa perlakuan) & 0,00 & 0,00 & 0,00 & $0,00 \mathrm{~b}$
\end{tabular}

Angka-angka yang diikuti oleh huruf yang berbeda pada kolom yang sama berbeda nyata pada Uji Jarak Berganda Duncan $\mathrm{P}=0,05$

Figures followed by different letter in the same column are significantly different at Duncan Multiple Range Test $P=0,05$

menunjukkan bahwa persentase kesembuhan perlakuan biofungisida berada di antara 50 - 83,87\% sedangkan perlakuan fungisida berkisar 36,36 - 80,65\%. Kontrol (tanpa aplikasi) menunjukkan intensitas serangan penyakit jamur upas meningkat setiap bulannya sehingga jika tidak diobati maka tanaman akan sulit untuk menyembuhkan dirinya sendiri kecuali faktor lingkungan yang dapat mempengaruhi perkembangan penyakit. 
Hasil pengamatan terakhir (3 BSA) menunjukkan bahwa perlakuan biofungisida setelah penyimpanan 3 bulan masih berpengaruh terhadap pulihnya penyakit jamur upas ini di Kebun Batang Serangan dengan rataan persentase kesembuhan tertinggi yakni $80,49 \%$ berbeda halnya dengan perlakuan lainnya yang berkisar antara 56,58-68,35\%. Hasil pengamatan tersebut menunjukkan bahwa biofungisida berbahan aktif mikroorganisme antagonis berupa bakteri Pseudomonas sp. mampu mengendalikan penyakit jamur upas. Hal ini sesuai dengan yang dikemukakan oleh Hasanuddin (2003) bahwa sejumlah mikroba atau mikroorganisme telah dilaporkan dalam berbagai penelitian efektif sebagai agen pengendalian hayati hama dan penyakit tumbuhan.

\section{KESIMPULAN DAN SARAN}

Berdasarkan data yang diperoleh selama pengujian maka dapat disimpulkan beberapa hal sebagai berikut:

1. Serangan penyakit jamur upas pada perlakuan biofungisida tanpa penyimpanan dan penyimpanan selama 1 dan 2 bulan dapat menurun sekitar 64,38-68,35\% di akhir pengamatan.

2. Biofungisida dengan lama penyimpanan 3 bulan masih efektif dalam menyembuhkan penyakit jamur upas dengan rataan persentase kesembuhan tertinggi sebesar 80,49\%.

3. Fungisida kimia berbahan aktif Triadimefon dan Heksakonazol mampu menyembuhkan jamur upas dengan kisaran persentase kesembuhan 56,58$63,41 \%$ pada pengamatan ketiga yakni 3 bulan setelah aplikasi (3 BSA).

4. Biofungisida berbahan aktif Pseudomonas sp. menunjukkan efektifitas yang nyata dalam mengendalikan jamur upas bila dibandingkan dengan kontrol dan tidak berbeda nyata dengan pengendalian secara kimiawi.

5. Pseudomonas sp. masih memiliki daya mengendalikan penyakit jamur upas, meskipun disimpan selama tiga bulan.

Adapun saran yaitu biofungisida yang disimpian selama tiga bulan masih efektif dalam mengendalikan penyakit jamur upas sehingga faktor kerapatan koloni bakteri pada setiap bulan penyimpanan perlu di ketahui dan di uji lebih lanjut hingga penyimpanan di atas tiga bulan.

\section{DAFTAR PUSTAKA}

Bell,C.R., G. A. Dickie, W. L. G. Harvey,. and J. W. Y. E. Chan. 1995. Endophytic Bacteria in Grape Vine. Canadian Journal of Microbiology 41: 46-53.

Budiman, A. dan K. Amypalupy. 2003. Penanggulangan Jamur Upas di Perkebunan Karet Kalimantan Selatan dengan Menggunakan Antico F-96. Warta Perkaretan 22(2-3): 64-76.

Fairuzah, Z. and Aidi-Daslin. 2011. The Effectiveness of Antagonistic Microorganisms to Control Pink Disease (Corticium salmonicolor) in Rubber Plant. Proceedings USU International Science and Technology Exhibition \& Seminar. Medan, 12-13 Juli. Universitas Sumatera Utara.: 82 88.

Gezahgne, A., J. Roux, and M. J. Wingfeld. 2003. First Report of Pink Disease on Eucalyptus camaldulensis in Ethiopia. www.bspp.org.uk diakses tanggal 1 Juni 2013

Hallman, J., A. Quadt-Hallman, W. E. Mehaffee, and J. W. Kloepper. 1997. Bacterial Endophytes in Agricultural Crops. Canadian Journal of Microbiology 43: 895-915.

Hasanuddin. 2003. Peningkatan Peranan Mikroorganisme dalam Sistem Pengendalian Penyakit Tumbuhan secara Terpadu. Jurusan Hama dan Penyakit Tumbuhan Fakultas Pertanian, USU Medan.

Jacobs, M.J., W. M. Bugbee, and D. A. Gabrielson. 1985. Enumeration, Location and Characterisation of Endophytic Bacteria within Sugar Beet Roots. Canadian Journal of Botany 63: $1262-1265$. 
Jetiyanon, K. and J. W. Kloepper. 2002. Mixtures of Plant Growth Promoting Rhizobacteria for Induction of Systemic Resistance Against Multiple Plant Disease. Biological Control 24: $285-291$.

Lutchmeah, R. S. and R. C. Cooke. 1985. Pelleting of Seed with the Antagonist Phytium oligandrum for Biological Control of Damping-Off. Plant Pathology 34: 528-531.

Mclnroy, J. A. and J. W. Kloepper. 1991. Analysis of Population Densities and Identification of Endophytic Bacteria of Maize and Cotton in the Field. in: Plant Growth Promoting RhizobacteriaProgress and Prospects (Eds.C. Ked, B. Koller and G. De'fage). Proceedings of the $2^{\text {nd }}$ International Workshop on Plant Growth Promoting Rhizobacteria, Intertaken. Switzerland, October 1419.: $328-331$.
Nelson, M. E. and M. L. Powelson. 1988. Biological Control of Grey Mold of Snap Beans by Trichoderma hamatum. Plant Disease 72 (8): $727-729$.

Patriquin, D. G. and J. D. Oring-Bereiner. 1978. Light Microscopy Observations of Tetrazolium-Reducing Bacteria in the Endorhizosphere, Maize and Other Grasses in Brazil. Canadian Journal of Microbiology 24: 734-74.

Pawirosoemardjo, S., H. Soepena, dan A. Situmorang. 1992. Sebaran Penyakit Utama Tanaman Karet. Prosiding Lokakarya Nasional Pemuliaan Karet 1992. Medan, 7 - 9 Desember. Pusat Penelitian Karet.: 209-216.

Sturz, A. V., B. R. Christie, B. G. Matheson, and J. Nowak. 1997. Biodiversity of Endophytic Bacteria which Colonised Red Clover Nodules, Roots, Stems and Foliage and Their Influence on Host Growth. Biological Fertilizers and Soils 25: $13-19$. 